\section{赤痢治寮血液ノ國際 的檢定法紹介}

細 谷省 吾

赤琍菌ガ腸管粘膜， $こ$ 二限局 シテ增殖 シ其產生スル毒素, 吸收ニョリテ赤俐ナ ル疾患ガ起ルモノト看做サレテ居ル從ツ テ本毒素，研究八赤闲病理. 治療上ノ根 本キナスモノデアルガ之二關スル諸家， 意見八溷沈タルモノガアル。從ツテ如何 ナル治療血清キ以テ治㞠二資セントスル カ二就テ科學的基礎力確固ナリト云七得 ナイノデァル此難問題キ決定スベク國 際聯盟衞生部主唱ノ下二各國ノ著名ナル 研究所二於テ赤㢉 擔當セル諸學者き Geneva =召集シテ第 1 回國際赤洞血清 檢定委員會 7 開催シタノ八 1921 年デア ツタ爾來常設委員會ク組織シ委員タル諸 學者ハ智囊き本問題二傾ケテ聯盟機關雜 誌ニ發表シ來ツタガPransnitz 呚授八命

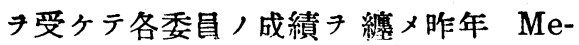
moranda on the international standardisation of therapeutic sera and bacterial products (Series of League of Nations Publications, III. Health, 1929. III. 10.) 中二綜說き揭ゲタ。

偶了日本醫學會出席 ノタメ來朝中， Madsen 教授八日本二於テモ本检定法，

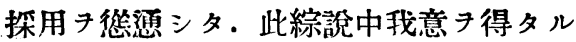
處尠少ナラザル事キ知ツタノデ簡單二之 き紹介セントスルモノデフル（詳細八日 本傳染病學會雜誌第 4 卷第 6,7 號二揭 載シタ)。

抗赤莉 (Shiga-Kruse) 血清:

C. Prausnitz

$$
\text { 第一章 (緒言) }
$$

赤琍菌ニハ多數ノ菌型ガ存在スルカラ
此治療血淸ハ多價デアル事ガ第一二望マ レル. Diphterie, Tetanus ト同樣二赤 莉二於テ八病原菌八㱠ド腸管粘膜， $i=$ 局在シテ居ルカラ病的機轉八細菌毒素， 作用二歸入可キモノデアル志賀菌八倍加 律二從ツテ抗毒素ニョツテ中和セラル、 Exotoxin 尹﨎生スルモノデアルカラ赫 琍菌中毒素形成二關シテ特殊，地位尹占 メテ居儿。本章二於テ八志賀菌毒素二關 スル著名ナル交獻き紹介シ殊二 1920 年 Olitzky 及 Kligler ガ本菌毒素二元說 唱導シタル事子特篗シテ居ル。兩氏 $ニ ヨ$ レバ本菌八全ク別個ナル 2 種/毒素キ分 泌シ Exotoxin 八中樞神經系統, $尹 7$ 侵 シ神經症狀惹起ス儿處，Neurotoxin デアリ. Endotoxin 八腸症狀子招來スル 處，Enterotoxin デアル事キ主張スル ノデアル。檢定委員會，指令ニヨツテ各 委員ハ之ヨ箃重二複試シタガ Exotoxin ト Endotoxin ガ別然別種ナル二ッ।物 質ナリト云フ Olitzky 等，所說 ル事八出來ナカツタノiナラズ志賀菌毒 素ノ內击ナル役目演ズルモノ八Exotoxin ソノモノデァル事が諸家一致シテ 之キ認メタノデアル。

茲二於テ各委員八志賀血清，信賴三得 ル standardisation 二努力キ集中シ之ガ 達成セラレタ曉二八本法ニヨツテ檢定セ ラレタル强カナル志賀抗毒素カ臨牀上使 用スル二適當ナリヤ否ヤタ確メントシタ ノデアル。第 1 回議會二於テ (1921 年)議 決シタ事項八 (1) 各研究所八血清. 培養 及毒素习交換シ检定上種々ノ方法及種々 ，實驗動物 于使用入可キ事。(2)血清 antitoxic and anti-endotoxic potency 尹检査ス几事. (3) 志賀菌/數株き以テ 多價血清き製造スルキ要セザル事.（4） 
志賀菌以外，赤闲菌二對スル乭疫血清， 調製及ビ其檢定き暫ラク論ゼザル事」等 デアル。

本研究, 協調二參與ス几研究所泣ビ二 研究者モ傳染病學會雜誌二記載シタ。

\section{第二章 志賀赤浰菌毒素}

(1) ブイョン毒素:一 $\mathrm{pH} 8.0$-8.8 二達 スル樣ナ「アルカリ性ブイョン」尹用フル 時八强力ナ毒素ガ得ラレル。

(2)若1寒天培養/生理的食監水又八 蒸餾水浮游液 以テ自家融解き起サシメ テ强力ナ毒素ガ得ラレル。

( 3 ) ,,Waschwassergift" :一寒天培養

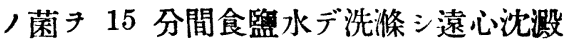
ニョッテ菌體キ除去スル事ニヨッテモ强 キ毒素キ得ル。

（4）加熱又八Toluol 尹用七テ殺菌シ タルモノモ毒素トシテ使用サレル。

(5) Wellcome Institut 八寒天培養

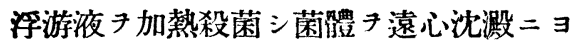
ッテ集メ之チ乾燥シ磨碎スル。

(6) Frankfurt. 研究所八 ,Integral toxin”ト稱 シテ寒天培養, 浮游液きン ノマ、低溫. 眞空中二乾燥シタルモノォ 使用スル。

是等，毒素，內血淸检定上孰レチ使用 スルモ不可ナラザル事が證明サレタ．唯 ダ constant ノ毒力 保有スル事及ビ Maus 二注射スルタメニ八液量ガ小ナル 事が必要ナノデアル。

海猽及鼠八實際的ノ實驗二八不適當デ アル反之家兔卜 Maus 二於テ八諸現象ガ 殆ド完全二本行スル Dosis certe lethalis (確實致死量)八 $1500 \mathrm{~g}$ ／家鬼二對シテ 八. $15 \mathrm{~g}$ ， Maus 二對スル量ノ約 5 倍 デアル。體重き同ジニシテ考へルトMaus 感受性八家鬼ノ約 20 分, 1 二相當
ル。

Neurotoxin $ト$ Enterotoxin 7 明確 二區別シ得ルト云フ Olitzkr 等, 所說き 復試シテ何人モ之き承認 シ得ナカツタ 事. 種々ノ異ナレル方法き用七テ得タ毒 素ガ同樣ナ作用き有スル事. 家兔及Maus 二對スル毒素ノ作用が相本行セル事. 種 々ノ毒素キ用ヒテ製造シタ種々ノ乭疫血 清ガ titration キ行フ場合二同ジ樣ナ結 果ガ得ラレル事及一ツノ炛疫血清キ種々 ノ方法デックツタ試驗用毒素二對シテ檢 定スル場合二モ同漾ナ結果ガ得ラレル 事」等八赤琍毒素ノ構造ガ homogeneous ナル事キ暗示スル事實デアル。

\section{第三章 抗浾浰血清ノ製造:}

此草二於テ如何ナル方法ガ馬キ用ヒテ 强力ナル免疫血清キ得ルニ最善ナリヤキ 論ジテ居ル。

\section{第四章 抗赤梨血清ノ}

\section{檢定 (titration)}

检定ノ標準トシテ血清ノ凝集價刃八感 染防禦作用习用七几事八全然不適當デア ツテ抗毒價タ決定スル方法ガ最善ナル事 八吻論デアル。之二八混合法卜治療法 (Curative test)トノニッノ方法が考へラ レルガ賽際上八前者郎毒素抗毒素八混合 注射法/そガ目的二副へルモノト云フ可 キデアル。

（a）動物，選擇二就テ八家兔及、Maus ノ靜脈內注射法ノミガ檢定上適當デアル 事二一致シタ兩者孰レチ使用スルモ感受 性ノ individual ノ相違八免レル事八出 來ナ1。檢定委員會二於テハ Maus titration二使用スル事二一決シタノデア ル蓋シ Maus ガ常二廉價デアリ容易二 多數テ使用スル事ガ出來ルシ從ツテ個々 ニョル感受性, 相違モ澤山, Maus $尹$ 使 
用スル事ニヨツテ或ル程度,迄八 neglect シ得ルカラデアル。

(b) 检定上使用不可 $\neq$ Maus / 數二就 テ八毒素ト血清ノ各稀釋液卜ノ混合每: 少ナクトモ 3 匹き使用スルガ實際上 3 匹 八尠ナ過ギル英國ノ公ノ規則デハ各混合 液ニ少クトモ6匹き使用スル。

(c) titration ノタメ二使用ス可キ素 毒, 量:-

最少致死量，何倍き用フ可キカ二就テ 諸家, 意見ハ一致シナイガ毒素ノ量, 問 題八始メ考へラレタ程重大ナモノデハナ イノデアル。检定委員會デハ致死量き基 準卜七ズニ「ヂフテリ一血清破傷風血清 ノ如ク標準血清二基礎 オォキ之ニョッテ 中和サレル樣ナ毒素, 平均, 價丹检定上 使用スル事ニ一決シタノデアル。

(d) 檢定上如何ナル毒素キ撰ブ可キカ 二就テ色々ノ强サノ血清き種々ノチガッ タ毒素き使用シテ檢定シテモ精確二比較 ノ出來ル樣ナ成績キ示ス事ガ制明シタノ デ检定上如何ナル毒毒き使用スベキカト 云フ問題ハアマリ重要ナ事柄デハナクナ ツタノデァル故二委員會八此點二關シテ 八單二安定ナ毒素（タトへバ乾燥毒素） 如キ) ヨ使用スル事き薦メルニ過ギナイ。

(e) 志賀毒素卜抗毒素卜，關係

兩者間ノ中和ガ倍加律二從つモノト考 ヘラレテ居タガ委員會ノ主唱ノ下二行八 レタ呼究デ八或ル程度迄疑問ガ起ツタ， デアル。毒素量ノアル極限內デハ此方則 二從つガ極限外デ八方則二從ハナイ樣デ アル。此原因八 Endotoxin 二歸ス可キ モノデアルカモ知レナイ。

(f) $\mathrm{L}_{\circ}$ (Dosis neutralisata) 及 $\mathrm{L}_{+}$ (Dosis non-neutralisata)

赤利血清，检定八「ヂフテリ一破稘風
ノ場合卜同樣二毒素ノ最少致死量フ基礎 トセズ二標準血清キ單位トナス可キ事ハ 勿論デアル。此血清キ antiseptica キ添 加セズ二低溫デ乾燥シ. 真空內二貯藏 ス ル。使用二際シテ glycerineト生理的食盃 水卜ノ混合液 (glycerine 2: 食礐水1) 指定サレタル分量二溶カシテ使用スル。

赤利素素/場合二 adjustment $尹 \mathrm{~L}$ 。 二對シテナス可キカ及ハ $\mathrm{L}_{+}$二對シテナ ス可キカノ問題ハ本毒素二對スル感受性 ガ動物個々二依ツテカナリ相違スルモ， デアルカラ「ヂフテリー。破賃風毒素, 場合卜同日二論ズル事八出來ナイノデア ル。本血清檢定二際シテ現令一般二採用 サレテ居儿實際方法八使用シタ Maus， $\frac{2}{3}$ 刃ハソレ以上ノ生存尹可能ナラシメ ル樣ナ毒素ト抗毒素トノ混合き,,neutral”、呼ビ. 反之 $\frac{2}{3}$ 及ハソレ以上， Maus ‡整ス樣ナ混合き, non-neutral” ナリト云フ。カ、ル基礎ニ基ヅイテ供試 毒素き標準血淸二對シテ adjust スルノ デアル。

云七換へレバ血清, Dosis neutralisataト八上述ノ方法ニョツテ制定シタ供 試毒素ト此血清トタ混合シタ場合 $=\frac{2}{3}$ 及ハソレ以上ノ生存习許ス樣ナ血清ノ量 チ意味スル。反之血清, Dosis nonneutralisata ト八此場合使用シタ Maus ノ $\frac{2}{3}$ 又ハソレ以上ヨ整ス樣ナ血清ノ量 ヨ指スノデァル。故二赤琍血清ノ檢定八 常二 $\mathrm{L}_{0}$ 及 $\mathrm{L}_{+}$，兩者キ決定スベキデテ ル。

(g) 國際單位及試驗方法，確定

以上ノ力法二準據シテ Schlossberger 等八英獨日儿標準血清尹比較シ

英: 獨：日本 $=1: 3: 45$

ノ比キ見出シタ。又 Kolle等ニヨレバ波 
菛血清八獨逸血淸ヨリモ2 倍乃至 4.2 倍 强力デァッタ。Geneva，检定委員會八 1 獨逸單位 $=36$ 國際單位 ナル事テ承認シタ。

Geneva，會議二於試驗，實行二關 シテ次ノ指令が決定的二定メラレタノデ アル。郎千

檢定八專ラ志賀菌カラツクツタ乾燥毒 素二對シテ血清, 抗毒素量き決定スル事 ニョツテ行フ可シ。此際毒素, 同一量ト 遥降的二稀釋シタ血清トキ混和シ $37^{\circ} \mathrm{C}$ 45 分放置シタ後其 0.5 c.c. 宛名各混合液 每: $=3$ 匹 (最沂八 6 匹) 宛，Maus（體重 八日本二於テ八 $12-15 \mathrm{~g}$ ) ，靜脈內二注 射スル。注射後 18 時間内二死ンダ Maus 八勘定二入レナイデ7 日間觀察 キ續ケ ル。標準血清八眞空,「アムプール內二 乾燥シテ貯藏シ各アムプール」ニ八血清 , Dosis neutralisata $\vdash$ Dosis nonnetralisataトタ記載スル事尹要ス。丁 抹ノ標準血清八

Dosis neutralisata $=\frac{1}{200} \mathrm{c} . c$.

Dosis non-neutralisata $=\frac{1}{300} \mathrm{ccc}$ デアツタ。

Copenhagen /國立血清研究所八乾燥 シタ多量/供試毒素及標準乾燥血清タッ クリ. 各國二供給スル。此標準血清八 Frankfurt 研究所カラ送ラレタ志賀菌 株, „Behring Werke”株キ以テ 4 頭 儿馬匹尹免疫シテ製造シ。探血後數日以 內二防腐劑チ加へズ二低溫乾燥シ五酸化 燐上二. 真空內二攝氏 2 度二貯藏スべシ 之キ使用スルニ八Glycerin 2 分. 生理

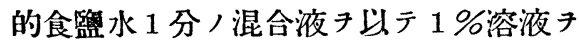
ツクル事キ要スル。

乾燥試驗用毒素八，,Behring Werke” 株 48 時間寒天培養, 菌, 蒸餾水浮游液 F $58^{\circ} \mathrm{C} 20$ 分 加熱シ遠心沈澱シテ集メタ 菌體子乾燥器內デ乾燥シ真空アムプール 二眝藏シタモノデアル。而シテ乾燥毒素 ノ新鮮ナ溶液八每:日製造スル必要ガア ル。標準血清, $\frac{1}{200}$ c.c郎 Dosis neutralisataト此毒素溶液トタ混合シタ場合二 ,,ne tral” ニナル樣ナ毒素, 量及ビ血淸 $\frac{1}{300}$ ca. 郎 $千$ Dosis non-neutralisata 毒素卜 混和シテ丁度 ,non-neutral” ニナル樣ナ毒素, 量き決定スル事が必要 デアル。

國際單位 I. U. 二關シテハ Madsen ノ提案ニョリテ標準血清, $1 \%$ 溶液 1 c.c. ガ 200 I.U. チ含么事. 云ヒ換へレバ乾 燥標準血清 $1 \mathrm{~g}$ 八 20.000 I.U. 尹含ム 事ガ必要デアル。

(h) 各地二於ヶル比較检定試驗, 結果

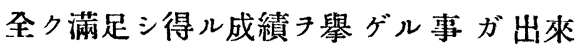
タ。

立二記載シタ國際單位及檢定法八英國 二於テ公式二採用サし獨逸. 佛闌西二於 テ八. 此研究 二 麿與 シタ二大研究所郎 Pasteur 研究所及 Frankfurt 實驗的治 療研究所モ之き採用シタ。之き要スルニ 8 年間ニワタル各委員, 努力二侬ツテ志 賀菌性赤浰治㞠血清製造及检定上二國際 的協調ガ得ラレタノジアル。是八全ク抗 毒性赤利血清尹臨牀的二赤琍治療二試 得ル基礎き與へタモノト云フ可キデア ル。 